\title{
Dialogue
}

Sniffing Oceania's Behind

VICENTE M DIAZ

The Contemporary Pacific, Volume 24, Number 2, 323-344

(C) 2012 by University of Hawai'i Press 


\section{Sniffing Oceania's Behind}

Vicente M Diaz

To us in the Pacific, history is a living thing. It embodies the essence of our past and rationalizes our present. [I appreciate] that this might not be what you mean when you use the word "history" in its usual sense.

Ratu David Toganivalu, Opening Address, Pacific History Association Conference, i 985

\section{Contortions}

Ratu David Toganivalu's allusion to Pacific history's vitality and instrumentality came at a point in his keynote address at the 1985 Pacific History Association Conference in Suva, Fiji, after he had disclosed the intimacy of his stakes in the professional association. His grandfather, born in the nineteenth century, was a keeper of Fijian traditional knowledge and genealogies who had in turn learned these from his own grandfather. Pacific history's vitality and instrumentality, we might say, are also about the legitimate and the legitimizing (or delegitimizing) relationship between one's genealogy and the ability to control the narrativization of the past. In the Pacific, this is an old truism.

While the bulk of Toganivalu's keynote address was also a fairly tired regurgitation of other truisms in and of Pacific history-for example, that the narrativization of the past in the Pacific has too long been the preserve of foreigners reliant on foreign source materials, and that modern development is leading inexorably to the loss of valuable indigenous knowledgehe shifted slightly a few moments later to admit indigenous complicity in the state of affairs. "Let us confess," he atoned, that "we lack the skills, or the time, or sometimes . . . the interest, to absorb [history], digest it, and pass it on" (Toganivalu I985, IO). It is also clear that in the context of

The Contemporary Pacific, Volume 24, Number 2, 324-344

(C) 2012 by University of Hawai' $i$ Press 
his lament, Toganivalu's reference to absorbing and digesting-to "passing on"-history refers to the lineal and linear transmission of important knowledge of the indigenous past to the next generation, but I want to suggest that the allusion can just as easily refer to the more familiar bodily functions of methane expulsion and waste excretion. So too I want to suggest that Toganivalu's reference to history as an embodiment of the "essence" of our past, quoted in the opening epigraph, can just as well, if not even better, be understood in relation to olfaction as to immutable or timeless, even romantic, ontological substances. What forms of the past can we encounter through smell in general, but in specific association with the anus in particular?

On one level, this essay pays tribute to the late Epeli Hau'ofa, the Tongan anthropologist, satirist, sage, clown, and dreamer, who was arguably the leading visionary in the field of Pacific Islands studies. In an age of decolonization and postcolonization, when anthropologists and historians rediscovered each other's spheres to collaborate on theorizing and doing Pacific cultural and political histories, Hau'ofa pulled back a bit from academia and wrote ribald tales of Islanders and their rear ends. When Pacific studies began to give the politics of narratology a vigorous tugging, Hau'ofa opened a center for Oceanian arts behind the main campus of a struggling regional university in an island nation (Fiji) that had itself fallen seriously into the fringes of international, and some say academic, respectability. In these and other ways-mentorship and love come to mind-Hau'ofa built and sustained an oeuvre that provoked a rethinking and redoing of the study of Pacific cultural and political pasts and presents. Of the many that comprise his writing, two critical threads interweave in my tribute to Hau'ofa: (I) the use of Oceanic ecologies and epistemologies to inform the narrativization of indigenous cultural pasts in the Pacific and (2) systematic as well as whimsical ways of confronting the high seriousness, including the naive and even dangerous realism, of political statecraft and academic pretension.

It is especially for this second sensibility that I have chosen to spend a large part of this essay examining the figure of the anus in Hau'ofa's famous Kisses in the Nederends (1995), a story that Teresia Teaiwa has characterized as a "wicked satirical allegory of economic, ecological, and cultural neocolonialism" (2000, I06), which she herself had earlier "reread" as an explicitly political act of moving beyond the confines of naive realist discourse (I999). Poking my nose where one probably shouldn't, my objective is to sniff out what, in particular, the anus in Hau'ofa's 
"wicked allegory" can tell us about how to conceptualize the past and what, more generally, olfaction can signal. My broader goal is to nod us in the direction of an olfactory history of Oceania in order to augment if not challenge canonical methods still heavily reliant on literacy and visuality and on other commonplace rhetorical and aesthetic conventions. ${ }^{1}$ For if Bernard Smith helped us to understand the extent to which Western art and evolutionary sciences relied on, even pioneered, visual conventions in their efforts to comprehend and represent that specific type of landscape called the Pacific Island-including its flora, its fauna, and its inhabitants and their cultures $(1985,4)$-then perhaps it is time we ask ourselves just what kinds of memories might be triggered, and what kinds of fights must be waged with whom, by learning to smell Islander cultural and political pasts as a form of politicized historiographical practice. Perhaps the assessment is long overdue, insofar as modernity has constructed its multiple forms through a systematic (but not thorough) privileging of sight and visuality over smell and olfaction (see Classen I993; Classen, Howes, and Synnott 1994; Smith 2007). ${ }^{2}$ To be sure, Pacific historiography does have a secondary archive of literature on oral traditions and on orality, ${ }^{3}$ although to the best of my knowledge, we don't have a single monograph on nasality or olfaction as a way of accessing the past. On this count, anthropologists and sociologists "of sensuality" (but not focused on the Pacific) are ahead. ${ }^{4}$

Smells are transitory, though they can also persist and even come and go and come again. They can be short-lived, long-lasting, permanent, or serial. They can be light or heavy, stinky or heavenly. Whether permanent or fleeting, repulsive or attractive, smells are, or can be, powerful signs of prior events, conditions, or processes and as such are indexical in that they point to something else often not visible or audible. Smells also foreground, as a matter of import, the subject who does the smelling (the one whose nose knows) and therefore add social or cultural specificity to the matter at hand. As we know, smells are also powerful—some say the most powerful-triggers of memory, which in turn is a complex discursive process and product with its own complicated sets of relationships to history. ${ }^{5}$ However, my theoretical interest in olfaction is less concerned with accessing the past via memory triggered by smell than it is with the more modest idea that smells are associated with things that are meaningful and people who matter with respect to the (ongoing) past and who, for whatever reasons, are not or cannot be captured or recorded in that supposedly more permanent record called written documents and the visual conventions 
that underwrite their various claims to authority. Smells, both despite and because of their transitory characteristics, can conjure many interesting meanings, including those that have nothing to do with original sources. And so, while smells might be strong triggers of memories, they can also summon other significant associations that are just as meaningful and are equally legitimate markers of the past. In this essay, Hau'ofa's story of the anus is likewise as good a heuristic device as any to get us sniffing in the general direction of a different historiography, one that he also elaborated on in a series of nonfiction essays to which I now turn.

\section{PAsts to ReMEMber}

Following the publication of his hugely influential essay "Our Sea of Islands" (Hau'ofa I994), Hau'ofa published the historiographic essay "Pasts to Remember," which served as the epilogue to Robert Borofsky's collection of critical essays titled Remembrance of Pacific Pasts: An Invitation to Remake History (2000). In "Pasts," Hau'ofa trumpeted the need for an indigenously oriented historiography for Oceania that could coexist with what he called "mainline" or Western, especially modern, historiographies. "Let others do their reconstructions of our pasts;" he wrote, "we have dialogue with them, we form alliances with some. But we must have histories-our roots and identities-that are our own distinctive creations" (Hau'ofa 2000, 458-459). According to Teaiwa, even his tremendous admiration for US President Barack Obama's ability to forsake "ideological dogma for the purpose of building dialogue and community," an audacity that Teaiwa said made Hau'ofa's "eyes glitter" (20I0, I07), was still not enough to dissuade him from insisting on the need for us to write "our own histories," to prevail upon "our roots and identities," and to advance "our distinctive creations" (Hau'ofa 2000, 459).

In his own tribute to Hau'ofa, James Clifford parsed the generative and semiotic tensions in Hau'ofa's cultural, political, and historical works to identify what Clifford tellingly called an "expansive regional vision"; an "immanent universalism"; an "alter-globalization"; and even, "oxymoron permitted, an indigenous cosmopolitanism" (2009, 239-240). In these sensibilities, Clifford likened Hau'ofa to Kanak leader Jean-Marie Tjibaou of New Caledonia (see Waddell 2009). Both men, asserted Clifford, were "bent on reinventing the Pacific Way in new circumstances. Post independence euphoria was gone, and they confronted the structural realities of neocolonialism and globalization, along with their possibilities. 
Both were committed to the renewal and transformation of local traditions, to strengthened 'indigenous' spaces. And both refused to be limited by exclusivist ethnic or national politics" (Clifford 2009, 239). But whereas Clifford's project was to map Hau'ofa's "hopeful vision," partly to recontextualize it favorably against charges of Hau'ofa's naive romanticism in "Sea of Islands," mine attends to other sensate elements elsewhere in his corpus of work. To get there, or as Hau'ofa put it in his historiographic essay, to get the "ball rolling," we must ground ourselves in what he called "ecologically based oral traditions" that have two primary foci: the first, a concentration on the people, by which he specifically meant the "ordinary people, the forgotten people of history, who have coped and are coping with their harsh realities, their resistance and struggles to be themselves and hold together"; the second, what he called the "notion of ecological time," in order to capture "traditional" notions of time in contrast to modern conceptions that stress linear and lineal, particularly evolutionary and teleologically based, cumulative progression and development (Hau'ofa 2000, 458-459). He had in mind nonlinear, especially cyclical conceptions of history, though he acknowledged linear traditions in Oceania and cyclical traditions in the West (as in Christianity).

Hau'ofa's examples are well known among Pacific studies scholars. For ecologically based narratives, he cited 'Okusitino Māhina's anthropological exegeses of Tongan oral traditions (I992, I993). For traditional conceptions of time, he used the Fijian and Tongan language terms for "time in front, or ahead" (gauna i liu and kuonga mu'a)—whose Hawaiian cognate for the past is ka wa mamua (the time in front or before)—and invoked Lilikalā Kame'eleihiwa's contrasting of ka wa mamua with ka wa mahope (the time which comes after, or behind). In an already famous passage, Kame'eleihiwa declared, "It is as if the Hawaiian stands firmly in the present, with his back to the future, and his eyes fixed upon the past, seeking historical answers for present-day dilemmas. Such an orientation is to the Hawaiian an eminently practical one, for the future is always unknown, whereas the past is rich in glory and knowledge. It also bestows upon us a natural propensity for the study of history" (I992, 22-23). Now, I am not qualified to test the claim of Hawaiian "natural propensity" in relation to the study of history; furthermore, Kame'eleihiwa's claim would seem to run directly counter to Ratu Toganivalu's confession about contemporary Islanders not being able, let alone interested, in history. However, in the potent realm of fiction, and particularly in the mode of the extremely absurd—here the anus is exemplary—Hau'ofa also seemed to be gesturing 
toward other natural propensities of Islanders that are also ecologically based and therefore very real among "the common people." Here, I contend, farts are especially exemplary. Through farts, and other meaningful behavior associated with it, the anus enjoys in Kisses a ubiquity and centrality to such a degree that it can oscillate in status from that of principal setting, to principal action, to protagonist in the narrative. While setting, action, and character begin on page one, the reader actually needs only go so far as the book's title to smell what I mean. I mean, you've heard of the Annales School? La longue durée? Hau'ofa's tale ushers in what might be called the Anals School of Pacific History, or the long derriere. La tongue in the derriere? But here I jest in the way that Hau'ofa jested. In a different mode, let's return more conventionally to the past as that which has transpired behind us (or "before," as in what transpired before the present time) in a lineal, teleological sense. To do so, let's turn from Hau'ofa's academic essays to his absurdist Kisses in the Nederends in order to look "behind us" and sense just how this behind can trigger other shapes of Oceanic pasts.

\section{KISSES}

At the end of Kisses in the Nederends, Oilei Bomboki sits in a plane next to his beloved spouse, Makarita, heading from New Zealand to his home country of Tipota. After having tried numerous traditional and other unconventional cures for what turns out to be a serious case of anal fistulae, Oilei had finally sought medical treatment in New Zealand. The procedure was not successful, and in desperation, he went to a nearby "special clinic" headed by an enigmatic mystic with whom Oilei had earlier enjoyed a brief but interrupted healing session. It was in their reunion that Oilei was cured. Now, Oilei peers out the window, and Hau'ofa, who in real life also suffered an acute case of fistulae, tenders not a reflection so much as a disclosure: Oilei's ass

had been preached at, prayed upon, exorcised, breathed into and out of, sung and danced. It had been exploded, jabbed, blown, hummed, needled, steamed, smoked, carved, discarded, transplanted, race-transformed, sex-changed, nosed and kissed back to life. No human arse had been subjected to so many trials and tribulations. No human orifice had gone through hell to emerge in the end so strong, so healthy and so wise. He and his lowliest organ had been called upon to the great task of saving humanity from its headlong rush toward the Apocalypse, and ushering in a new millennium of lasting peace, prosperity 
and happiness. [Oilei] remembered Bulbul's prophetic words, "Marxism and Communism have shaken the twentieth century; the Pan Pacific Philosophy for Peace and the Third Millennium will shake the twenty-first and beyond." (Hau'ofa 1995, I 53)

Hau'ofa's tale of Oilei's tail, we might say, holds promise: promise, and hope, for Pacific historiography, to say the least.

From its cover page to its closing, and structuring its entire narrative, Hau'ofa's Kisses presents the anus as privileged locus of social, cultural, and political drama and agency in the fictional Pacific Island nation of Tipota. The plot begins and thickens thus: One day Oilei Bomboki wakes up to excruciating pain in his behind, which causes flatulence enough to levitate him and to almost cost him his marriage to Makarita when he farts in her face while she is tending to his sore bum. An inventory of farts throughout the book yields a veritable bouquet of cultural truths. I will return to this inventory in due course.

The storyline involves a rapid succession of "sidesplitting" Hau'ofian episodes (Teaiwa 2010, I06) in which Oilei consults a number of traditional healers whose treatments range from finger-plunging exorcisms (Hau'ofa I995, 34-36) to incantational enemas propelled by the blowing of conch shells, one of whose side effects is to induce a humming "from his blowhole" before it explodes into "one of the loudest farts" anybody has every heard (46). The former (the failed exorcism) is conducted by one Losana Tonokas, the descendant of a chiefdom that had only been "nominally" converted to Christianity in the nineteenth century and had since remained a "sanctuary" for the old gods (24). On the question of native Christianity in the Pacific, we discover that while the Tipotans more generally "had been Christians for over a century, they had not shed their fear of spirits. The new religion merely downgraded their native gods to the rank of malicious ghosts, who roamed everywhere and did horrible things to people. The Holy Ghost might reign in heaven, but Tipota was the happy hunting ground for the lesser spirits" (24). Here, mission history and the histories of native conversion are brought into the present in an episode that caricatures a local minister who pleads with Oilei to turn to the power of prayer. Even before Oilei can be persuaded to try it, the minister suddenly drops dead-killed, perhaps, by divine providence, suggesting God's actual disdain for those who preach in his name. The only interesting thing about this minister comes when Makarita blurts, "What the fucking ..." in reaction to his sneaking up on her from behind. His 
response-“Dear oh dear, we must never say 'fuck"” (I 8)—also provocatively suggests the true colors of the many self-appointed preachers in the Christian Pacific.

Still another treatment by a traditional healer involves smoking Oilei's bum with special leaves while he smokes cigars made from leaves of a different plant $(74-75)$. In this session, Oilei's inadvertent switching of the leaves for the anal and oral cavities leads to a reversal in which Oilei begins to breathe through his ass and fart through his nose. When this program fails, the traditional healer experiences a "vision" that for him explains the cause of the affliction: there rages inside Oilei a civil war between humanlike creatures called Tuktuks, of which there are two types: those that inhabit the "higher" regions of the body and those that dwell in the lower, particularly in the anal cavity (86). Only when "relative peace" is achieved in Tuktuk land can Oilei be healed (86). This particular drama foreshadows Oilei's holistic healing under Babu Vivekanand. Vivekanand's philosophy and movement is called "The Third Millennium." Its goal of healing (self, society, and world) is predicated on the fundamental "oneness" of all things in the cosmos (99). All ills, he explains, are caused by the disruption of this totality, including the social and political stratification of otherwise equal elements of all parts. Take the anus, for example, which Babu likens to the lower orders of society: "It does the most unpleasant jobs and no one would like their daughters to marry garbage collectors" (IOO). Its historical maligning, he continues, is "class prejudice of the worst order. The great teacher, Jesus of Nazareth, once told his disciples to behave toward the least members of society as they behaved toward him. We must behave likewise toward our anuses" (IO०). Vivekanand's holistic therapy pivots the anus around the nose and lips but also invokes all of the senses. In the passage that follows, we get visual clarity, sonic harmony, and tactile fortitude on top of olfactory love. Babu's, to be sure, is a heroic holism whose romanticism is matched only by absurdity:

It is only when you are able to lovingly and respectfully kiss your own anus, and those of your fellow human beings, that you will know you have purified yourself of all obscenities and prejudices, and have overcome your worst fears and phobias. You will then be able to see with utmost clarity the true nature of beauty, which is the essence of the unity and equality of all things. For while you assign different values to different parts of your body and consider some of them dirty, disgusting and shameful, you will continue to assign the same values but with even greater intensity to similar parts of other people's bodies. That is, of course, a short route to hating and loathing them. Only when 
you treat every part of your body equally can you begin your journey toward true love. And once there, your life will harmonise with the One Infinite, and all your pains and agues will disappear. Sickness, disease and death strike us because of disharmonies in our existence. But when we synchronise our lives with the Eternal Programme of the Universe, we will live forever. (IOI)

This theory is put into action through a series of yogic exercises designed to "reconcile your anus with the rest of your being and with the One Infinite" (IO2). The first is a maneuver that will enable you "to see your anus closely for so often and for such prolonged periods that it is not strange and disgusting anymore ... to your nose, [your anus] will be as the fresh bud of spring. . . At the end of all of this you will have written a poem, 'Ode to My Lovely Anus,' which you may put to music and perform to rapturous audiences" (IO2). The second maneuver is designed to achieve higher elevation, that is, to enable one to kiss and meditate on one's own anus and those of others.

Oilei is quite smitten by this philosophy, both for its apparent utilityafter Babu's first kiss, Oilei feels so much better that for the first time in the story he becomes randy for Makarita, who promptly tells him to fuck off-but also because it has brought him internal peace. This positive experience is rudely terminated, or at least suspended, however, when Babu is arrested for lewd behavior and when a German Jewish psychoanalyst tries to convince Oilei that his condition is an anal fixation caused by an Oedipal complex. Despite Oilei's warnings to watch his mouth, the psychotherapist insists that Oilei basically wants to fuck his own mother. It is only after Oilei tries to kill the doctor that funds are secured to send him to New Zealand for modern medical treatment. But in New Zealand, before a lecture hall of medical students, Oilei undergoes a procedure that involves excising his already brutalized anus and replacing it with that of a white feminist. However, his body rejects the transplant, and in a lastditch effort to save his life, the remains of his original anus are retrieved from the waste bin and hurriedly stitched back. Then he is wheeled to the Whakapohane Clinic, "a special clinic" run by "a peculiar lot," which also turns out to be headed by none other than Babu Vivekanand, the sage with the peculiar philosophy. At Whakapohane, Oilei (who had long since passed out) gradually comes to, and finds himself surrounded by Makarita, friends, and associates, the cast of the traditional healers, and of course, Vivekanand, who has converted them all. Together they sing the "great hymn of the Third Millennium" and proceed to plant in his anus 
"the collective kiss of love and respect" (I49-I 50). And for an additional month, Babu treats Oilei by inserting his nose in Oilei's anus in order to ensure complete recovery. It is in this way that Oilei is "nosed back to life" (I53).

\section{Nosed Back to Life}

Hau'ofa's fixation with anality features a veritable bouquet of olfaction, that is, of scenes that specifically involve the sense of smell, including that of taste, which is deeply interconnected to smell. To be sure, his preoccupation with the anus is not equivalent to smelling history, which is the business of the nose (but also of the taste buds, the brain, and all the other senses that affect in different, still unknown ways the overall processing of the meanings behind the smell). But what Hau'ofa's narrativized anus does for us is jar conventional historiographic sensibilities from their perch on the high altar of realist or "mainline" modality and upset their lingering tendencies to focus on important people and events or nationalist preoccupations, allowing us to delve instead into the more chaotic social world of the subaltern, whose struggles are allegorized in the epic battles that take place around and even within the anus. ${ }^{6}$ In the seriousness of the absurdity of the tail's tale, the anus is the real Oceania, what Hau'ofa also lovingly referred to in Kisses as "the soul essence of the universe." Here, once again, I gloss "essence" in terms of olfaction as opposed to that which is purportedly timeless and eternal. For my purposes, this "soul" is a heuristic device, a springboard into smell proper, and in what follows, I offer an inventory of more or less fleeting scents that index cultural and political pasts and presents worthy of further ventilation, as well as additional attention to those who are doing the smelling. After all, as Hau'ofa said, this is our history.

\section{SMELLING IsLANDS}

My initial interest in smell comes from a long-standing intrigue based in my experiences in Carolinian seafaring, where it is often said that a good navigator can smell an island long before he (very seldom a "she") can see it (Diaz 2002, 20I I; Gladwin I970, I45). Some examples include the ability to identify certain islands by the fragrance or stench of their predominant fruits. Polowatese navigators have claimed the ability to identify Nama because of its papayas. ${ }^{7}$ The pungent scent of ripened breadfruit is 
another traditional clue to the presence of land. As these examples reveal, scent is especially important in locating atolls in particular because of the absence of mountains, cliff lines, or hills.

In Carolinian seafaring, menstruation is another particularly powerful smell, which is especially favored by sea spirits and tricksters like Olofat, often given as the principal reason why men don't like to have women on board the canoes. ${ }^{8}$ This, of course, is but one way that "traditional" canoe culture is engendered and sexualized in postcolonial as well as colonial representation, and it informs the classic binary wherein men work the ocean (engendered feminine) to produce mobility (routes), while women work the land (engendered male) for the purposes of imaging and reifying deep stability and tradition (roots). These same discourses inform technical aspects of canoe design and construction. The improper carving of a canoe can result in the inadvertent creation of a spot or space in the vessel that might attract unwelcome spirits. Conversely, skilled carvers can build into their craft roosting areas precisely to "contain" such spirits. An example is the so-called Olofat's seat, a small triangular-shaped area in a canoe that is also said to resemble a woman's pubic region. ${ }^{9}$

A final example from seafaring histories is not directly associated with the "behind" but, like Olofat's triangle, features genitalia—another part of the anatomy proximate to both anuses and the subaltern-although in this case it involves the heroic use of male organs. In his classic study of traditional seafaring in the Pacific, David Lewis told of the celebrated I-Kiribati navigator who was so adept that in the calmest of seas, when the feminized ocean refused to divulge her secrets, he had only to lay his testicles on the bow to detect the slightest motion to discern direction (since waves and swells are also associated with stars and island chains) ( 1994, I27). One can almost get a whiff of this particularly visceral and highly problematic practice. Indeed, the scents and sensibilities wafting around Oilei's broken bum, we might say, circulate amid a host of other cultural and historical cognates in Micronesian cultural and political history. They bring out dimensions of our past that likewise have not been treated in any real, substantive way, although elsewhere I have called critical attention to these precisely as dimensions of olfaction that matter (Diaz 20IO).

For instance, there is the potent fusion produced historically between seventeenth-century Spanish Catholic and precontact Chamorro spiritualities that involves the sense of smell and that constitutes key elements of Fr Diego Luis de San Vitores's legacy among the Chamorros of the 
Mariana Islands. San Vitores's mission among the Chamorros in I 668 has the dubious distinction of being the first Christian mission in Oceania; his assassination at the hands of a local chief in 1672 started the process to canonize him, a movement that took a giant step at the end of the twentieth century when the Chamorro archdiocese succeeded in having Rome beatify the man. Like all good Jesuits, San Vitores championed Ignatius Loyola's famous Spiritual Exercises in which "the senses occupied critical ground" (M Smith 2007, 64). Jeffrey Chipps Smith elaborated, "Ignatius was first and foremost a sensualist, in that he clearly recognized that one should utilize all of one's capabilities when attempting to understand God" (2002, 35). Loyola, we are told, stressed the importance of smell "for a genuine understanding of hell, something that demanded that one 'smell with the smell of smoke, sulphur, dregs and putrid things." He was "especially interested in [the role of] the senses of smell and taste in animating memory and facilitating communion with God.... Ignatius urged one to "smell and to taste ... the infinite fragrance and sweetness of the Divinity, of the soul, and of its virtues'" (M Smith 2007, 64). San Vitores's own reputation for holiness (his fama marytrii) featured olfaction as a sign of divine providence (Diaz 20I0, I 56-I 58 ). One example will suffice here. In July I648, San Vitores and his confessor, Fr Diego Ramirez, had been traveling overland from Madrid to the Jesuit seminary in Villarejo, Spain, where they arrived on the eve of the Feast of Saint Ignatius. We pick up the story-which comes from Ramirez's seventeenth-century deposition-before supper on the night of their arrival:

among other mortifications that were practiced after the manner of those held at lunch, one was to kiss the feet of the community as is usually done. When they came to kiss the feet of our guest [San Vitores,] they noticed the excellent smell they exuded, so that for only that reason they deliberately and repeatedly looked at him and recognized him among the rest. Many marveled at such novelty and later told me about it as if it were something mysterious. I for my part[,] intending to see if he went to bed, entered his room while he was disrobing and quietly took one shoe and tried to smell it. I must confess that it did smell extraordinarily well. No tanned hides that I had ever smelt in my life gave me such comfort. (Positio I98 I, 80)

Ramirez explained that the two had been traveling for days, under the heat of the season, and that it was a physically demanding journey because of which San Vitores had "sweated excessively-a thing that is not conducive to good odor, much less of the feet." For these reasons, Ramirez 
concluded that "whether this was natural in the boy ... or whether it came from a higher source ... which is my personal belief[,] considering the quality of the smell ... only God knows." Ramirez later said that he "was sorry that [he] did not take with [him] one or both shoes" (Positio I98I, 80-8I).

The Chamorro were already primed for the pump, we might say. In Chamorro, the term and practice for deferential show of respect and reverence to one's elders is ñgingi' (to sniff) (Topping, Ogo, and Dungca I975, 3 I6). To this day, the Chamorro cultural code of inafa'maolek (to keep things "good," which carries connotations of social harmony and balance) prescribes that one fañgingi' (sniffs) an elder or, of course, a priest when first encountering him or her in a social or private situation. Here is a Chamorro theory and practice of subjectivity that glosses "essence"cultural and social substance-with smell. One imbibes the "essence" of an elder not only to show respect but also hopefully to partake in some of what that body has to offer. The miasmic quality is captured in Fr Román María de Vera's Diccionario Chamorro-Castellaño, which glosses one form of ñgingi'-eñginge-as inspiracion, which of course comes from the root spiros, or spirit (originally the Holy Spirit) (1932, 203). And in Chamorro "folklore" and "superstition"-these are external classifications of course-the sudden whiff of certain smells, especially of flowers where none are found, is understood to be a sign of otherworldly presence. This belief accords well with traditional funerary practices across Micronesia, such as perfuming the deceased (Ashby 1985, I9I). In Chamorro, the term for a fragrant scent, as of a perfume or flower, is paopao (Topping, Ogo, and Dungca I975, 26I). While I do not know, at least not from firsthand experience, the extent to which some Chamorros still practice the tradition of making and using "love perfumes" to ensnare a target, the practice abounds elsewhere in Micronesia as a testimony to its efficacy and the power of its practitioners. Palauans and Pohnpeians are especially noted for their "love magic," but none of their concoctions rivals, in my understanding, the reputation of what the Mortlockese have come to call the "Satawan Atomic Bomb," an "intolerably powerful" potion that "is most potent when used by a man whose strong love for a woman is matched only by the woman's disdain for the man" (Ashby I985, II9; emphasis added). This is basically rape perfume, and it is telling that the traditional Satawan love potion was so named in the wake of US nuclear testing in the region. It indexes the same point I want to make about the histories of Chamorro Catholicism with its Spanish and 
Chamorro cultural tributaries: the products are powerful cultural syncretisms bequeathed to us by ongoing histories of imperialism, neocolonialism, and Islander postcolonial responses and contributions to them. My sense is that we in or from the Pacific-Islanders and non-Islanders, historians or otherwise- have yet to adequately understand, much less resist or otherwise contest sufficiently, such historical forces, probably because of colonial and neo- or postcolonial modes of being and modes of apprehension, not least those that privilege visuality, literacy, and even orality over olfactory and other marginalized senses and sensibilities.

This last point returns more squarely to the critical question about the relationship between these modes and colonial and postcolonial, especially hetero-normative patriarchal forms of cultural self-representation and historical analyses. After all, even these examples of historical syncretism stink of male privilege and power.

In her "less than authentic" read of Kisses in the Nederends, Teresia Teaiwa advanced the argument that Hau'ofa created "a 'Polynesian body' that is unmistakably counter hegemonic" (I999, 255-256). For Teaiwa, the historic and contemporary "Polynesian" body is a highly problematic colonial, neocolonial, and postcolonial construct notwithstanding (or perhaps precisely because of) the fact that the category has become a powerful site for nationalist and regionalist anticolonial articulations in Oceania. David Hanlon made an analogous argument about the category "Micronesia"-writing, incidentally, in relation to Hau'ofa's "Our Sea of Islands" essay (Hanlon 2009).

Teaiwa contended that in Kisses, "Oilei's anus is perhaps the most radical literary site available for criticizing ... Gauguinesque representations of the 'Polynesian' body" and added that Hau'ofa's "focus on the anus avoids the typical phallocentrism of Pacific Island novels" (I999, 256). Teaiwa considered Gauguinesque representations to be primitivist discourses that lend themselves readily to "militourist" appropriations (Teaiwa 2000, 200I), a term and analytic she coined and developed to describe the mutually empowering relationship between militarism and tourism in the Pacific. Not coincidentally, it is precisely in this vein, or cavity, that Teaiwa suggested and deployed the ability to read Makarita, Oilei's "no-nonsense" wife, as a possible "prototype of the [Pacific Woman] political activist" (Teaiwa I999, 258). Teaiwa pointed out that though Makarita is skeptical initially about Babu's Third Millennium philosophy, she capitulates and becomes "integral" to her husband's recovery. Perhaps, wondered Teaiwa, this conversion is not unlike that by which 
"many Pacific Island women come to political consciousness and take up activism when the bodies of their loved ones are affected—or infected—by large and previously mysterious forces" (I999, 258).

But Teaiwa didn't stop at reading the possibilities of Hau'ofa's Makarita. She "up-ended" Hau'ofa's tale by the political practice of "writing" a fictional postscript "that can really happen," one in which Makarita ends up kissing Oilei's butt a final time before leaving him and the fictional country of Tipota for the real country of Fiji where she will join a nuclearfree organization while also dancing her own ass off in the process. Now there's a real historical behind or before us, into which political leadersand we Islander academics-might just want to stick our collective noses (Teaiwa 1997).

This essay ORIginated as a paper delivered at the 20 io Meeting of the American History Association, held in San Diego, California. I thank Teresia Teaiwa, Damon Salesa, Christine Taitano DeLisle, and the three anonymous referees for excellent critical feedback. I am grateful also to David Hanlon and Terence Wesley-Smith for encouraging me to pursue the disciplinary unorthodoxies that Pacific histories require.

\section{Notes}

I I am not advocating the abandonment of the other senses and modalities, which of course would be impossible. For starters, Hau'ofa was a writer, and he championed the visual arts, among other forms, in his vision and practice for the Oceania Center for the Arts and Culture at the University of the South Pacific in Suva, Fiji. Moreover, this is an essay, and the reader is not smelling it. Even then, the cognitive sciences teach us that none of the senses operate independently of the others and that each of the senses contributes in one way or another to how or what humans perceive through any one particular sense, while a deficit or damage to one sense can also result in the strengthening or heightening of perception through others. In the first instance, for example, what we see strongly affects what we think we taste. In the second instance, blind individuals have been known to develop the ability to "see" the shapes of sounds, or, in cases of human echolocation (Downey 20II), humans can be taught to "see" their way through a field of objects by clicking their tongues (or using specialized devices) and hearing the shapes and locations of objects in their vicinity, like bats do. 
2 Aristotle taught that the sensate reality comprises the five senses of sight, sound, smell, taste, and touch. Modern cognitive sciences, however, identify a total of nine to nineteen other senses, including equilibrioception (balance and acceleration) and nociception (pain). For an even longer list and additional references, see Wikipedia's “List of Common Misconceptions," http://en.wikipedia .org/wiki/List_of_common_misconceptions [accessed 5 May 20II].

3 See Grimmage I981; Latukefu I968; Mercer I979; Mitchell I970; Moore and Munro I996; Osorio I992; Tamasese I994; Waiko I986; Wendt I987.

4 See Gell I977; Howes 2003, 2005; Ingold 2000, 2007; Lankauskas 2006; Law 2005; Parkin 2007.

5 For a cultural study of the relationship between memory and history, see Sturken I997. In Pacific studies, the links between memory and history are treated in White, Fujitani, and Yoneyama $200 \mathrm{I}$ and in Camacho $20 \mathrm{II}$.

6 This rhetorical jarring draws some of its potential power from the anus's (and excreta's) power to repulse, which in so doing foregrounds critical attention to the role of trauma in social processes of subject and object formation and meaning construction, including the social relations of power involved in regulating proper or normative behavior between subject and object. Here, my nod is to Julia Kristeva's theory of abjection (I982), invoked in relation to the discursive power of, in this case, the anus, but also in relation to my bid to call attention to the subaltern-like subjects and objects that are necessarily marginalized, sacrificed, or silenced in favor of more tasteful (read: proper, pure) matters.

7 I thank Polowatese navigator Mannas Sikau for this information.

8 Spirits are also attracted to other smells-recent sexual intercourse, flowers, and perfumes-not just menstruation.

9 The idea of "containing" Olofat through the tactical control of a triangular area in a canoe called "Olofat's seat" was explained to me by the late Polowatese navigator Sosthenis Emwalu.

\section{References}

Ashby, Gene

I985 Micronesian Customs and Beliefs. Revised edition. Eugene: Rainy Day Press.

Borofsky, Robert, editor

2000 Remembrances of Pacific Pasts: An Invitation to Remake History. Honolulu: University of Hawai'i Press.

Camacho, Keith L

20I I Cultures of Commemoration: The Politics of War, Memory, and History in the Mariana Islands. Honolulu: Center for Pacific Islands Studies and University of Hawai'i Press. 
Classen, Constance

I993 Worlds of Sense: Exploring the Senses in History and Across Cultures. New York: Routledge.

Classen, Constance, David Howes, and Anthony Synnott

I994 Aroma: The Cultural History of Smell. New York: Routledge.

Clifford, James

2009 Hau'ofa's Hope. Distinguished Lecture, Association for Social Anthropology in Oceania. Oceania 79:238-249.

Diaz, Vicente M

2002 Sacred Tensions: Navigating Tradition and Modernity. Micronesian Educator 9:54-62.

2010 Repositioning the Missionary: Rewriting the Histories of Colonialism, Native Catholicism, and Indigeneity in Guam. Pacific Islands Monograph Series 24. Honolulu: Center for Pacific Islands Studies and University of Hawai'i Press.

20I I Voyaging for Anti-Colonial Recovery: Austronesian Seafaring, Archipelagic Rethinking, and the Re-mapping of Indigeneity. Pacific Asia Inquiry 2:2I-32.

Downey, Greg

20II Getting Around by Sound: Human Echolocation. Neuroanthropology: Understanding the Encultured Brain and Body, Public Library of Science (PLoS) blog, I 4 June. http://blogs.plos.org/neuroanthropology /20I I/06/I 4/getting-around-by-sound-human-echolocation/ [accessed I 8 November 20II]

Gell, Alfred

I977 Magic, Perfume, Dream. In Symbols and Sentiments. Cross-Cultural Studies in Symbolism, edited by Ioan Lewis, 25-38. London: Academic Press.

Gladwin, Thomas

I970 East Is a Big Bird: Navigation and Logic on Puluwat Atoll. Cambridge, MA: Harvard University Press.

Grimmage, Bill

I98 I Oral and Written Sources. In Oral Tradition in Melanesia, edited by Donald Denoon and Roderic Lacey, I I 5-I22. Port Moresby: University of Papua New Guinea.

Hanlon, David

2009 The "Sea of Little Islands": Examining Micronesia's Place in "Our Sea of Islands." The Contemporary Pacific 2 I:9 I-I IO.

Hau'ofa, Epeli

I994 Our Sea of Islands. The Contemporary Pacific 6:I48-I6I. First published in A New Oceania: Rediscovering Our Sea of Islands, edited 
by Eric Waddell, Vijay Naidu, and Epeli Hau'ofa, 2-I6. Suva: School of Social and Economic Development, The University of the South Pacific ( I993). Republished in Hau'ofa 2008.

I995 Kisses in the Nederends. Honolulu: University of Hawai'i Press. First published by Penguin Books, Auckland (1987).

2000 Pasts to Remember. In Remembrances of Pacific Pasts: An Invitation to Remake History, edited by Robert Borofsky, 453-47 I. Honolulu: University of Hawai'i Press. Republished in Hau'ofa 2008.

2008 We Are the Ocean: Selected Works. Honolulu: University of Hawai' $\mathrm{i}$ Press.

Howes, David

2003 Sensual Relations: Engaging the Senses in Culture and Social Theory. Ann Arbor: University of Michigan Press.

Howes, David, editor

2005 Empire of the Senses: The Sensual Culture Reader. Oxford: Berg. Ingold, Tim

2000 The Perception of the Environment: Essays in Livelihood, Dwelling and Skill. London: Routledge.

2007 Earth, Sky, Wind, and Weather. Journal of the Royal Anthropological Institute (NS), SI9-S38.

Kame'eleihiwa, Lilikalā

I992 Native Land and Foreign Desires: Pehea Lā E Pono Ai? Honolulu: Bishop Museum Press.

Kristeva, Julia

I982 Powers of Horror: An Essay on Abjection. New York: Columbia University Press.

Lankauskas, Gediminas

2006 Sensuous (Re)Collections: The Sight and Taste of Socialism at Grūtas Statue Park, Lithuania. Senses \& Society I:27-52.

Latukefu, Sione

I968 Oral Traditions: An Appraisal of Their Value in Historical Research in Tonga. Journal of Pacific History 3: $335-143$.

Law, Lisa

2005 Home Cooking: Filipino Women and Geographies of the Senses in Hong Kong. In Empire of the Senses: The Sensual Culture Reader, edited by David Howes, 224-24I. Oxford: Berg.

Lewis, David

I994 We, the Navigators: The Ancient Art of Landfinding in the Pacific. Second Edition. Honolulu: University of Hawai'i Press.

Māhina, 'Okusitino

I992 Tongan Traditional History: Tala-e-fonua. PhD Dissertation, The Australian National University. 
I993 The Poetics of Tongan Traditional History, Tala-e-fonua: An Ecology-Centred Concept of Culture and History. Journal of Pacific History 28:IO9-I2I.

Mercer, Peter M

I979 Oral Tradition in the Pacific. Journal of Pacific History I4: I 30-I 53. Mitchell, Roger

I970 Oral Tradition and Micronesian History: A Microcosmic Approach. Journal of Pacific History 5:33-4I.

Moore, Clive, and Doug Munro

I996 The Nature of Pacific History: A Bibliography. Journal of Pacific Studies 20:I 55-I60.

Osorio, Jonathan Kamakawiwo'ole

I992 Songs of our Natural Selves: The Enduring Voice of Nature in Hawaiian Music. In Pacific History: Papers from the Eighth Pacific History Association Conference, edited by Donald Rubinstein, 429-432. Mangilao: University of Guam Press and Micronesian Area Research Center.

Parkin, David

2007 Wafting on the Wind: Smell and the Cycle of Spirit and Matter. Journal of the Royal Anthropological Institute (NS), S39-S53.

Positio (Positio Super Vita et Martyrio Ex Officio Concinnaia)

I98I The Cause of the Beatification of Ven Diego Luis de Sanvitores, Apostle of the Marianas. Deposition on the Life and Martyrdom, compiled and translated by Fr Juan Ledesma, sJ. Rome: The Sacred

Smith, Bernard Congregation for the Causes of Saints, Historical Section 94.

I98 5 European Vision and the South Pacific. Second edition. New Haven, Ст: Yale University Press.

Smith, Jeffrey Chipps

2002 Sensuous Worship: Jesuits and the Art of the Early Catholic Reformation in Germany. Princeton, NJ: Princeton University Press.

Smith, Mark Michael

2007 Sensing the Past: Seeing, Hearing, Smelling, Tasting, and Touching in

Sturken, Marita History. Los Angeles: University of California Press.

I997 Tangled Memories, the Vietnam War, the AIDS Epidemic and the Politics of Remembering. Berkeley: University of California Press.

Tamasese, Tuiatua Tupua

I994 The Riddle in Samoan History: The Relevance of Language, Names, Honorifics, Genealogy, Ritual and Chant to Historical Analysis. Journal of Pacific History 29:65-79. 
Teaiwa, Teresia

I997 Real Natives Don't French Kiss When They're Making Love. In Dreadlocks in Oceania, edited by Sudesh Mishra and Elizabeth Guy, 7-I9. Suva: Department of Literature and Language, University of the South Pacific.

I999 Reading Paul Gauguin's Noa Noa with Epeli Hau'ofa's Nederends: Militourism, Feminism and the "Polynesian" Body. In Inside Out: Literature, Cultural Politics, and Identity in the New Pacific, edited by Vilsoni Hereniko and Rob Wilson, 249-264. Boulder, co: Rowman \& Littlefield.

2000 bikinis and other s/pacific n/oceans. In Voyaging through the Contemporary Pacific, edited by David Hanlon and Geoffrey M White, 9I-I I 2. Lanham, MD: Rowman \& Littlefield. First published in The Contemporary Pacific 6:87-109 (1994).

$200 \mathrm{I}$ Militourism and the Native: Articulations in Oceania. PhD Dissertation, University of California, Santa Cruz.

20I0 The Thing About It Is. In Epeli's Quest: Essays in Honor of Epeli Hau'ofa, compiled by Terence Wesley-Smith. The Contemporary Pacific 22:105-108.

Toganivalu, Hon Ratu David

I985 Opening Address. Pacific History Association Conference, University of the South Pacific, Suva, Fiji, 27 June. Manuscript in author's possession.

Topping, Donald, Pedro M Ogo, and Bernadita Dungca

I975 Chamorro-English Dictionary. Honolulu: University of Hawai'i Press.

Vera, Román María de

I932 Diccionario Chamorro-Castellaño. Manila: Cacho Hermano.

Waddell, Eric

2009 Jean-Marie Tjibaou: Kanak Witness to the World; An Intellectual Biography. Pacific Islands Monograph Series 23. Honolulu: Center for Pacific Islands Studies and University of Hawai'i Press.

Waiko, John D

I986 Oral Traditions among the Binandere. Journal of Pacific History $2 \mathrm{I}: 20-38$.

Wendt, Albert

I987 Novelists and Historians and the Art of Remembering. In Class and Culture in the South Pacific, edited by Antony Hooper, Steve Britton, Ron Crocombe, Judith Huntsman and Cluny Macpherson, 78-9I. Suva: The University of the South Pacific. 
White, Geoff, Takahashi Fujitani, and Lisa Yoneyama

$200 \mathrm{I}$ Perilous Memories: The Asia-Pacific War(s). Durham, nc: Duke University Press.

\section{Abstract}

Part tribute to the late Epeli Hau'ofa and part reflective historiography, this essay examines the figure of the anus in Hau'ofa's short story Kisses in the Nederends in order to open up an inquiry into an olfactory history of Oceania. My broader goal is to augment if not challenge canonical methods still heavily reliant on literacy and visuality, and realist modalities that I believe are inadequate to the task of apprehending subaltern aspects of Oceania's ongoing past.

KEYWORDS: Pacific Islands history, Pacific Islands historiography, Native Pacific cultural studies, narratology, Epeli Hau'ofa 